\title{
The Effect of Students' Reluctance of Studying History on Their Level of Historical Culture
}

\author{
Dr. Hani Hatmel Obeidat \\ Associate professor \\ Curriculum and Instruction Department, Faculty of Educational Sciences \\ Al - Hussein Bin Talal University, Jordan \\ E-mail: hatmalko@yahoo.com \\ Dr. Mahmoud Sulaiman Bani Abdelrahman \\ Assistant professor \\ Curriculum and Instruction Department, Faculty of Educational Sciences \\ Al - Hussein Bin Talal University, Jordan \\ E-mail: Abugaith66@yahoo.com \\ Dr. Khaled Ateyat \\ Assistant professor \\ Curriculum and Instruction Department, Faculty of Educational Sciences \\ Al - Hussein Bin Talal University, Jordan \\ Dr. Mansoor AL-Arood \\ Ministry of Education, Jordan
}

\begin{abstract}
This study aimed to identify the effect of the students' reluctance in studying history on their level of historical culture. To achieve the goal, two instruments were prepared. The first one was about the reasons of students' reluctance and consisted of (24) items. The second instrument was an achievement test to detect the students' level of historical culture consisted of (36) questions. The validity and reliability of the instruments were checked. The first instrument was applied on a sample of (94) second secondary students who did not study history. The second instrument was applied on a sample of (195) students who studied and did not study history. The results showed that: the students' reluctance mostly was because the history teachers did not give the students the opportunity to dialogue and participate; the teachers' questions focus on memorizing and remembering; the history subject is theoretical where there is no practical application; the lack of relation among the history subjects; and the terms in history have nothing to do with the students' real life situations. The results showed also that the students' level in their historical culture who studied history was (83.1) which was higher than what is accepted educationally. While the students' level in their historical culture for those who did not study history was $(49,61)$.
\end{abstract}

As it is appeared, there is an inverse relationship between the students' reluctance in studying history and their level in historical culture.

Keywords: Students' reluctance, History subject, Historical culture

\section{Introduction}

History is the events that vary in importance depending on the look at it, the goals from which we can get lessons for the future (Nabhan, 2004). Several concepts have been appeared about the history with people. German historians believe that history means the thing that happened, while French historians believe that it is the 
knowledge and narration. Narration means the history (Zaidi, 2009). Onsko (2000) argued that history does not stop at the narrative events of the past, but the work in the interpretation and development of human beings by linking past events and their reflections on the present and future. Obeidat (1985) said that history is an organized record that talks about realities of the past and links between them in order to prepare the individual to the life of the future. So, history is not just stories and novels from the past, but extended to link the past and the future. Past events and problems affect the present.

Ibrahim (1994) said that history is a weapon of society and its equipment to understand the present and its interpretation. Ideas, customs, traditions, ways of individual's life, social relations and all aspects of life at the present can not be understood properly only in light of the understanding of the past. Nabhan (2004) considered history as a record of experiences and human rights that have been exposed to overcome the problems throughout the ages. Human beings can not get rid of his past that he suffers from and from he can get lessons and lessons on the problems and crises which have gone in the past.

It is clear from the above that human beings cannot develop themselves away from the past from which lessons can be derived and sermons that help in solving the problems encountered in daily life. From here we can recognize that history has a great importance in human life as it is considered the most importance science. So, the one who does not understand his past won't understand his present and can't be able to plan for his future effectively.

The teaching of history of great importance for our students in schools and universities, as it serves as a beacon that guided them in their lives. Teva (2004) saw that the objectives of teaching history and the study of history are: understanding the importance of the past, to accommodate students how things happen and let them acquire the comparison between historical events and understanding multicultural societies and privacy. Lutfi (1980) identified the objectives of teaching history as follows:

*increasing the people's culture by identifying with some aspects of the societies' life that have emerged at some point in the past, so that experienced by the reader's mind and imagination.

*the study of history is a fun, mental and abstracted from which the communities' fate can be felt in its trips and its decline including disturbed life of the hopes and suffering.

*accommodate studies for seeing the effects and residues in some archaeological sites while Richburg and Nelson (1990) see the objective of studying history is not just a transfer or acquisition of abstract facts, but it contains linked information intended to develop the students' capacity to responsible decisions.

Al-Awadi (1986) saw that the most important objectives of the study of history was to know the historical facts, to acquire the ability to assess historical texts and learning to write history. Coleman and Hight (1995) viewed that the objectives of history teaching is to develop a sense of time and sequencing.

It is clear from the above that the teaching of history has several objectives. If those objectives were achieved by the students, they would bring to them many benefits. Where Ibahim (1999) and Husam (2003) viewed that history provides a variety of intellectual challenges and gives a sense of understanding the past and present. Also, it contributes to enhancing the communication between the student with the human societies in the past and present. Al-Qablawi (2004) believes that history contributes to building the spiritual and humanitarian work among students and to strengthen human relations among themselves. Sulaiman (1999) pointed that the benefits of the study of history is the development of moral values, sense of responsibility among students, appreciation for others and the development of learners' thinking about historical events. Al-Khraisha (1998) viewed that history contributes to an individual's personality through acquiring human experiences that have accumulated since the start of life to awaken the person and to restore confidence to the importance and ability to work and tender. Al-Laaqani (1979) considered that the study of history is a mean to understand the present and not just proud of the past glory of the predecessor but treating causal relationships between the previous and subsequent events and issues and their direct effect on the people's lives in the past and how to expand it for the present. But Barqi (2008) viewed that the most important benefits of the study of history are:

* to develop the changing idea with the learner and helping him to be able to participate in it .

* the development of ethical concepts and to encourage the virtues.

* to configure objective view of the learner through his awareness of the differing views of historians about the things, events and different motivations.

* to configure the positive effective citizen to serve his society's issues. 
* to develop the idea of international understanding and its effect on the promotion of human culture and development of social sentiment.

Othman (1980) viewed that the study of history is to earn the ability to historical inferences, acquisition and social skills, the ability to make judgments about incidents and persons, explain incidents and referred it to the original factors.

The study of history subject in the secondary stage in Jordan is considered one of the important subjects for its role in the development of the student's personality, providing him with the needed experiences, skills and trends development for him, the values which are considered a good of teaching history and of finding a good citizen who aims to serve himself, his society, his country and the world as a whole.

\section{Literature Review}

The subject of studying history subject was taken into consideration by researcher. Brophy, Vanstedright \& Bridn (1993) conducted a study that aimed to study the students' degree of understanding- who are moving to the fifth grade - the nature of history. The sample of the study consisted of (10) students. The interview method was used as the students were asked (23) questions. The results showed that a lot of students look at history as events occurred in the past or stories and novels accounted the important figures in history. Students were unable to determine the cause of importance of teaching history and nature of the work. Also, they found the presence of mixing with the concept of the historian and the archaeologist. While the aim of Yeager's and Davis's (1994) study was to identify the extent to which student-teacher of social studies in elementary stage acquired historical thinking skills. The sample was (120) students-teachers. The results indicated that the acquisition of student-teacher to historical thinking skills was low. Levistik's \& Barton's (1994) study sought to know the basic-schools in U.S.A students' understanding of the historical time. Open interview were held with (58) children from kindergarten to the fifth grade. The results showed that kindergarten children have the ability to historical discrimination and the children's abilities to distinguish increases as risen from one class to another. The results also showed that students were unable to link specific dates with specific background only in the fifth grade. But Levistik \& Barton's (1996) study aimed to know the extent to which students were able to put pictures in the correct historical period. The sample consisted of (58) students. The instruments of the study were observation and interview. The results showed that the students' historical knowledge was affected by the type of cultural material included in the images and the patterns of daily life which they live. Yeager \& Wilson (1997) conducted a study to know the effect of method of teaching social studies subject which is taught in Southeastern State in improving historical thinking skills by students-teachers for the secondary stage. The sample consisted of (30) students-teachers. Interview method was used to carry out the study. Those students were observed in an educational position in the classroom as they teach in the teaching practice program. The results showed that the methods of teaching social studies subject have a signified role to let students know the historical thinking skills and how to deal with them.

Al-Khraisha (1998) conducted a study to determine the level of knowledge of social studies teacher at the secondary stage in Jordan to the nature of history and the effect of sex, qualification and specialization variables. The sample of the study consisted of (140) teachers who teach social studies at the secondary stage. A test of (112) items was applied to test their knowledge of the nature of history. The results showed low level of knowledge of these teachers to the nature of history. The level was less than the acceptable level educationally $(85 \%)$. There were no significant statistical difference $(\alpha=0.05)$ in the level of knowledge of the nature of history due to sex and qualification. While there were differences due to specialization in favor of history specialization. Al-Safadi (1999) conducted a study to determine the level of knowledge of history teachers at the secondary stage for research and historical thinking skills. The sample consisted of (101) teachers who were teaching history subject at the secondary stage selected randomly. The results showed that the level of knowledge of history teachers in the historical thinking skills were below the acceptable level educationally (85\%). Edais (2004) conducted a study to find out about the reality of the historical thinking skills in the curriculum of history books for upper basic stage and the preparation of a unit for the development of those skills, students' knowledge and students' trends towards history subject. The sample of the study consisted of (100) students from the tenth grade. The results showed that there was low level of thinking skills in history books for the tenth grade and the presence of a positive trend in the tenth grade students about the history curriculum. Al-Douiri's (2006) study tried to disclosure of the level of history teachers' understanding the nature of history subject and its relationship to classroom practices in the basic stage in Jordan. The sample consisted of (30) teachers (male and female) selected randomly from who were teaching history for the sixth, seventh \& eighth grades. The results showed that the percentage of history teachers who have a high understanding of the nature 
of history was low, while the ones with medium understanding was average. The percentage of teachers who have low understanding of history was high.

From the previous literature review, the researchers concluded the following:-

- The current study is similar to the previous ones in terms of its focus on nature of history subject and the degree of students' understanding to the subject.

- The current study differs from the previous ones in terms of its focus on the national and historical culture with the second secondary literary stream students.

- The current study differs from all the previous studies that it will compare between the students' level of historical culture who have studied history subject and the ones who didn't study it.

- The current study differs from the previous studies in terms that it will seek the causes for the students' reluctance of studying history subject.

For all of the above, this study is a qualitative addition to the previous studies.

\section{Problem and Questions of the Study}

During the application of a study about students' level of understanding the argumentative issues in the Jordanian modern history textbooks, it was found that a large percentage of students didn't choose the history subject as it is an elective subject among other subjects. The researchers felt that this would affect the students' national historical culture. So, this study was to detect the effect of the students' reluctance of studying history subject as their national historical culture through answering the following questions:-

1- What are the causes of students' reluctance of studying history subject?

2- What is the second secondary students' historical culture level for those who studied the history subject?

3- What is the second secondary students' historical culture level for those who didn't study the history subject?

4- Is there a relationship between the students' reluctance of studying history subject and their historical culture level?

\section{The Importance of the Study}

The importance of the study is as follows:-

- The officials at the Ministry of Education in Jordan could benefit from the results of this study through knowing the real causes that lead to the students' reluctance of studying history subject.

- The Directorate of General Curriculum at the Ministry of Education in Jordan by identifying the effect of the history subject as an elective subject on the students' national historical culture.

\section{Definitions of Terms}

Students' reluctance causes: any obstacle that guides to let students be away from studying history subject and it is determined in the study appendix.

Students: the second secondary students who studied or did not study the history subject in the first secondary literary stream in Dair Alla Directorate of Education in Jordan.

National historical culture: it means the students' level in national historical culture in Jordan. It has been measured by a test intended for this purpose as it is in the appendix of the study.

\section{Limitations of the Study}

- The generalizations of the results are limited to the population of the study.

- The generalizations of the results are limited on the test which was prepared to measure the historical culture that consists of (37) items as it appears in the appendix of the study.

\section{Methodology}

\section{Population and Sample of the Study}

The sample of the study consisted of all the population. The sample consisted of (101) second secondary students who studied the Jordanian modern history subject (male and female) in Dair Alla Directorate of Education in Jordan. Also, the sample consisted of (94) first secondary students (male and female) who did not study the Jordanian modern history subject in Dair Alla Directorate of Education in Jordan. 


\section{Instruments of the Study and its Validity}

a. An instrument to measure the causes of students' reluctance of studying history subject.

b. An achievement test to measure the historical culture.

The following is how the instruments of the study were prepared:

a. An instrument to measure the causes of students' reluctance of studying history subject.

1. An open question was given to the second secondary students about the causes of students' reluctance of studying history subject.

2. The literature and previous studies have been consulted on the causes of reluctance (Al-Shaikh, 2000), (Ibrahim, 1994), (Parker, 1991), (Habib, 2003) and others.

3. In the light of the previous, a questionnaire was prepared consists of (40) items within two dimensions (subject's reluctance causes and students' reluctance causes).

4. The instrument was given to a jury, specialists in curricula and instruction, measurement and evaluation, psychology and Ministry of Education supervisors to find whether the instrument was appropriate for the study or not. Also, to express their opinions in the instrument in terms of adding, modification, deletion or by providing suggestions to enrich the subject. After taking the jury's views, the instrument was in its final form consisted of (24) items in two dimensions. Teachers' reluctance causes consisted of (10) items and the subject reluctance causes consisted of (14) items within a scale (large, medium, low).

b. An achievement test to measure the historical culture.

1. To prepare the test, it was referred to the Jordanian modern history textbooks and were analyzed in order to prepare a test to measure the national historical culture.

2. The test consisted of (36) questions in its first form.

3. The test was given to history supervisors, teachers of history subjects who are teaching secondary stage and to specialists of curricula of social studies. They were asked to read the test items and judge its suitability for measuring the students' national historical culture and make any adjustments they see appropriate. The views of the jury were taken into consideration. The number of items was (36) in its final form as a mean to measure the students' level of historical culture.

4. A question was given to the jury to determine the students' level of historical culture which is accepted educationally $(80 \%)$. This percentage is an equivalent to $(28.8 \%)$ of the total score of the test.

5. To correct the test, the correct answer was given one degree while the wrong answer was given zero.

\section{Reliability of the Instrument}

The reliability was calculated using Cronbach Alpha (KR, 20). The reliability coefficient of the instrument as a whole was (0.86).

\section{Statistical Analysis}

To answer the first, second, and third questions, means and standard deviations were used. But to answer the fourth question, Pearson correlation coefficient was used.

\section{Discussion of the Results}

\section{Question one:-}

What are the causes of students' reluctance of studying history subject?

To answer this question, means and standard deviations were used as seen in table (1).

It is clear from table (1) that the most causes of students' reluctance of studying history subject referred to:-

- "History teachers do not give an opportunity to students in participation and dialogue." It got the first order with a mean of (2.98) and a standard deviation of (1.06). It may be due to the fact that most history teachers who are in secondary schools with long experiences are still following the teacher's traditional role in which the teacher has the positive role as a sender and the student has the negative role as a receiver. Hence, they do not let the students to debate and dialogue. The reason may refer to the nature of the issues in history subject that do not 
require dialogue and discussion with the student. So, the teacher does not give an opportunity for dialogue and discussion.

-" Teachers' questions focus on memorizing and remembering." It got the second order with a mean of (2.93) and a standard deviation of (1.34). The reason may refer to the history teachers' views towards the subject that they are teaching that it requires memorizing and remembering more than understanding and comprehension. The other mental skills are consistent with the results as indicated in (Parker, 1991) \& (Habib, 2003).

-" History subject is a theoretical subject does not have practical application." It got the third order with a mean of (2.91) and a standard deviation (1.23). But " The terminology in history subjects has nothing to do with students' life" got the fifth order with a mean (2.86) and a standard deviation (1.28). The reason may refer to that the history subjects includes theoretical topics that talk about the past. Hence, the students' abilities to apply this information in the present is impossible as the information is far from the reality of students' life. From this, students feel of the unimportance of the history in their daily life. The subject matter that fulfill the students' needs is the one that they get benefits in their real life situations and consistent with what is indicated by (Al-Shaikh, 2000) \& (Ibrahim, 1994).

-"There is no connection among the history topics." It got the fourth order with a mean of (2.90) and a standard deviation (1.19). The reason may refer to that history subject talks about different old periods. Also, sometimes we see the old and modern history in the same text. From here, the student is dispersed and not being able to link ideas with each other.

\section{Question Two}

What is the second secondary students' historical culture level for those who studied the history subject?

To answer this question, means and standard deviations were calculated to answer the items as shown in table (2).

It is clear from the table that the average in the students' historical culture level for who those studied history subject was (29.97) from the full grade which is (36). This is an equivalent to (83.10\%) which is higher than what is accepted educationally $(80 \%)$. This means that Jordanian Modern History Subject forms a historical culture with students related to his country (Jordan) and the developments that took place in all economical, political, social, cultural and other fields. That helps in refining the student's personality.

\section{Question Three}

What is the second secondary students' historical culture level for those who didn't study the history subject?

To answer this question, means and standard deviations were calculated for the students' answers on the test items as shown in table (3).

It is clear from table (3) that the average students' historical culture for those who didn't study history subject was (17.86) from the total mark (36) and this is an equivalent to (49.61\%). This percentage indicates that the students' national historical culture was very weak due to the lack in their studies of history subject in the first secondary. That has a negative effect on their historical culture. Or it may be due to the lack of students' in history subject. Therefore, their historical culture was low. This finding corresponds with (Brophy, Vanstedrigh $\&$ Bridn, 1991) and (Al-Safadi, 1999) findings in their studies.

\section{Question Four}

Is there a relationship between the students' reluctance of studying history subject and their historical culture level?

To answer this question, Pearson correlation coefficient was used as shown in table (4).

Table (4) shows an inverse relationship between the students' reluctance of studying history subject and their historical culture level. This is normal, the non-study students for the history subject led to the weakness of historical culture.

\section{Conclusion and Recommendations}

1- To have history subject as a compulsory subject for students and not as an elective subject for its effect on the national historical culture they have.

2- Guiding history teachers to teach it in the historical way to provide thinking among students and to develop their dialogue and discussion. 
3- To put learning activities in the history textbook to interest students to study so as to make the students link between the events of the past and present in which they live.

4- The need to organize the topics in the history textbooks in chronological and logical order from the past to present and to have connections among the topics.

Note: Appendix parts one and two are available on request from the corresponding authors: abugaith66@yahoo.com or hatmalko@yahoo.com

\section{References}

Al-Awadhi, A. (1986). Teaching History with Historical Document and Educational Television. Ministry of Information, Kuwait.

Al-Douiri, M. (2006). Social Studies Teachers' Level of Understanding of the Nature of History and its Relationship to the Classroom Practices in the Basic Stage in Jordan. Unpublished Doctoral Dissertation, Yarmouk University, Jordan.

Al-Khraisha, A. (1997). Social Studies Teachers' Knowledge Level at the Secondary Stage in Jordan to the Nature of History and the Effect of Sex, Qualification and Specialization. Jarash Journal for Research and Studies, 3 (1), pp 135-170.

Al-Laaqani, A. (1979). New Trends in Teaching History. Books World, Cairo, Egypt.

Al-Qablawi, S. (2004). Efficiencies of Teaching Social Studies. Al-Shrooq House, Amman, Jordan.

Al-Safadi, H. (1995). Secondary Stage Social Studies Teachers' Knowledge Level of Historical Thinking and Research Skills. Unpublished Master Thesis, Yarmouk University, Jordan.

Al-Shaikh, R. (2001). History Course Explanation. Theories in the Philosophy of History. Ain for and Humanities and Social Studies Research, Cairo, Egypt.

Al-Zaidi, M. (2009). Methods of Historical Research. Curriculum Publication House, Amman, Jordan.

Barqi, N. (2008). Future problems and the Teaching of History. Cairo, Anglo Egyptian Bookshop, Egypt.

Brophy, J., Vanstedright, B \& Bredin, N. (1993). What to Entering Fifth Grade Know about U.S History? Journal of Social Studies Research, 16 (17), pp 2-19.

Coleman, J. (1995). The five keys to History Social Science, Social Studies review, 34 (2), p 14.

Edais, A. (2004). Forming an Educational Unit Based on the Historical Thinking Skills and Attitudes Towards the Study of History. Unpublished Doctoral Dissertation, Yarmou University, Jordan.

Habib, M. (2003). Teaching Thinking. Cairo, Arab Thought House, Egypt.

Husam, A. (2003). Methods of Teaching History to All Levels of Education. Osama Publication and Distribution House, Amman, Jordan.

Ibrahim, F. (1999). The necessity skills to learn history in the light of the Inquisitorial Method. Journal of Education, Qatar University, 9 (12), pp.120-126.

Ibrahim, K. (1994). Social Studies in the Curriculum of Education between Theory and Practice. Alexandaria, University Knowledge House.

Levstik, I. \& Barton, K. (1994). "Back when Goal was Around and Every" elementary children's understanding of Historical Time, Paper presented at the annual meeting of the American Educational Research Association, pp 4-8.

Levstik, I. \& Barton, K. (1996). They still use some of their past: Historical Salience in elementary children's chronological thinking. Curriculum Studies, 28 (5), pp 521-570.

Lutfi, Y. (1980). Around Historical Thought Curriculum. Krader's and his Brothers' Office, Beirut, Lebanon.

Nabhan, Y. (2004). Methods of Teaching Social Studies and Practical Application. Yafa Publication House, Amman, Jordan.

Obeidat, S. (1985). Basics in Teaching Social Studies and its Practical Applications. Assembly Press Jordanian Workers, Amman, Jordan.

Onsko, J. (2000). History story and students' thinking. Journal of Curriculum Studies, 22 (5), pp 443-462.

Othman, H. (1980). Methods of Historical Research. Cairo, Al-Ma'aref House, Egypt. 
Parker, W. (1991). Achieving Thinking and Decision Making Objectives in Social Studies, Handbook of Research on Social Studies, Teaching and Learning, edited by James Shaver. New York, Macmillan.

Richbury, W. Nelson, J. (1990). Using a Historical Incident to Focus on Value Formation. The Social Studies, 81 (2), pp 81-84.

Sulaiman, J. (1999). History Teaching Methods. Damascus University Publications, Damascus, Syria.

Teva, L. (2004). Teaching History. New York, Department of State Press.

Yeager, E \& Davis, J. (1994). Understanding the Knowing How of History. Elementary Students Teachers' Thinking about Historical Texts. Journal of Social Studies Research, 18 (2), pp 2-9.

Yeager, E \& Wilson, E. (1997). Teaching Historical Thinking in the Social Studies Methods Course: A case Study. The Social Studies, 88 (3), pp 121-126.

Table 1. Means and Standard Deviations of Students' Reluctance Causes of Studying History Subject Arranged in Descending Order

\begin{tabular}{|c|c|c|c|c|c|}
\hline $\begin{array}{l}\text { Item } \\
\text { No. }\end{array}$ & Order & dimension & item & Mean & SD \\
\hline 5 & 1 & 1 & $\begin{array}{l}\text { History teachers do not give an opportunity } \\
\text { to students in participation and dialogue }\end{array}$ & 2.98 & 1.06 \\
\hline 8 & 2 & 1 & $\begin{array}{l}\text { Teachers' questions focus on memorizing } \\
\text { and remembering }\end{array}$ & 2.93 & 1.34 \\
\hline 21 & 3 & 2 & $\begin{array}{l}\text { History subject is a theoretical subject does } \\
\text { not have practical application }\end{array}$ & 2.91 & 1.22 \\
\hline 19 & 4 & 2 & $\begin{array}{l}\text { There is no connection among the history } \\
\text { topics }\end{array}$ & 2.90 & 1.19 \\
\hline 20 & 5 & 2 & $\begin{array}{l}\text { The terminology in history subjects has } \\
\text { nothing to do with students' life }\end{array}$ & 2.86 & 1.28 \\
\hline 23 & 6 & 2 & A lot of ideas in the history subject & 2.75 & 1.25 \\
\hline 22 & 7 & 2 & $\begin{array}{l}\text { Studying history requires students' time and } \\
\text { effort. }\end{array}$ & 2.58 & 1.38 \\
\hline 18 & 8 & 2 & $\begin{array}{l}\text { History subject requires a lot of activities } \\
\text { and duties }\end{array}$ & 2.46 & 1.20 \\
\hline 7 & 9 & 1 & $\begin{array}{l}\text { Teachers' way of teaching history is far from } \\
\text { the reality of students' life }\end{array}$ & 2.41 & 1.30 \\
\hline 15 & 10 & 2 & $\begin{array}{l}\text { A lot of names and dates that require } \\
\text { memorizing }\end{array}$ & 2.36 & 1.36 \\
\hline 11 & 11 & 2 & The big size of the history textbook & 2.27 & 1.49 \\
\hline 1 & 12 & 1 & $\begin{array}{l}\text { The teacher lacks the skill of teaching } \\
\text { history }\end{array}$ & 2.21 & 1.37 \\
\hline 6 & 13 & 1 & The teacher's way in teaching is boring & 2.17 & 1.23 \\
\hline 12 & 14 & 2 & $\begin{array}{l}\text { The information in the history textbook was } \\
\text { very old }\end{array}$ & 2.15 & 1.51 \\
\hline 13 & 15 & 2 & $\begin{array}{l}\text { There is no excitement or suspense in the } \\
\text { information provided by the history book }\end{array}$ & 2.04 & 1.36 \\
\hline 4 & 16 & 1 & The inability of the teacher to put examples & 1.89 & 1.23 \\
\hline
\end{tabular}




\begin{tabular}{|c|c|c|l|c|c|}
\hline & & & from the local environment & & \\
\hline 3 & 17 & 1 & $\begin{array}{l}\text { The teachers do not use teaching aids for } \\
\text { students }\end{array}$ & 1.81 & 1.26 \\
\hline 24 & 18 & 2 & $\begin{array}{l}\text { The history subject does not raise the } \\
\text { students' motivation }\end{array}$ & 1.76 & 1.15 \\
\hline 17 & 19 & 2 & $\begin{array}{l}\text { Historical information is higher than the } \\
\text { students' level }\end{array}$ & 1.69 & 1.25 \\
\hline 16 & 20 & 2 & The school textbook lacks the teaching aids & 1.55 & 1.20 \\
\hline 9 & 21 & 1 & $\begin{array}{l}\text { Teachers used to be away from the } \\
\text { classroom subject with unrelated issues }\end{array}$ & 1.54 & 1.56 \\
\hline 2 & 22 & 1 & $\begin{array}{l}\text { The history teacher uses one method which } \\
\text { is delivering }\end{array}$ & 1.44 & 1.40 \\
\hline 10 & 23 & 1 & $\begin{array}{l}\text { The teacher does not take care of individual } \\
\text { differences }\end{array}$ & 1.28 & 1.31 \\
\hline 14 & 24 & 2 & $\begin{array}{l}\text { History textbook depends on memorizing } \\
\text { more than understanding }\end{array}$ & 1.14 & 1.27 \\
\hline
\end{tabular}

Table 2. Means and Standard Deviations of the Average answers on the items of the test for students who have studied the history subject

\begin{tabular}{|c|c|c|c|}
\hline Item no. & Order & Mean & $\mathrm{SD}$ \\
\hline 8 & 1 & 0.901 & 0.32 \\
\hline 19 & 2 & 0.891 & 0.34 \\
\hline 5 & 3 & 0.802 & 0.40 \\
\hline 18 & 4 & 0.851 & 0.40 \\
\hline 22 & 5 & 0.872 & 0.42 \\
\hline 23 & 6 & 0.843 & 0.42 \\
\hline 36 & 7 & 0.892 & 0.43 \\
\hline 34 & 8 & 0.832 & 0.44 \\
\hline 6 & 9 & 0.821 & 0.44 \\
\hline 10 & 10 & 0.812 & 1.14 \\
\hline 27 & 11 & 0.853 & 0.45 \\
\hline 21 & 12 & 0.803 & 0.45 \\
\hline 35 & 13 & 0.793 & 0.46 \\
\hline 31 & 14 & 0.882 & 0.46 \\
\hline 33 & 15 & 0.770 & 0.47 \\
\hline 3 & 16 & 0.863 & 0.47 \\
\hline 20 & 17 & 0.861 & 0.47 \\
\hline 28 & 18 & 0.783 & 0.47 \\
\hline 7 & 19 & 0.891 & 0.48 \\
\hline 1 & 20 & 0.802 & 0.60 \\
\hline 32 & 21 & 0.793 & 0.59 \\
\hline 14 & 22 & 0.874 & 0.49 \\
\hline
\end{tabular}




\begin{tabular}{|c|c|c|c|}
\hline 25 & 23 & 0.872 & 0.49 \\
\hline 11 & 24 & 0.854 & 0.49 \\
\hline 13 & 25 & 0.821 & 0.49 \\
\hline 26 & 26 & 0.723 & 0.49 \\
\hline 15 & 27 & 0.861 & 0.50 \\
\hline 29 & 28 & 0.781 & 0.51 \\
\hline 9 & 29 & 0.851 & 0.50 \\
\hline 24 & 30 & 0.824 & 0.51 \\
\hline 30 & 31 & 0.791 & 0.51 \\
\hline 4 & 32 & 0.853 & 0.52 \\
\hline 12 & 33 & 0.764 & 0.48 \\
\hline 17 & 34 & 0.811 & 0.49 \\
\hline 16 & 35 & 0.873 & 0.50 \\
\hline 2 & 36 & 0.754 & 0.47 \\
\hline Total & & 29.918 & 8.32 \\
\hline
\end{tabular}

Table 3. Means and Standard Deviations of the Average of students' answers on the items of the test for students who did not study the history subject arranged in descending order

\begin{tabular}{|c|c|c|c|}
\hline Item No. & Order & Mean & SD \\
\hline 5 & 1 & 0.766 & 0.42 \\
\hline 8 & 2 & 0.723 & 0.44 \\
\hline 21 & 3 & 0.712 & 0.45 \\
\hline 34 & 4 & 0.691 & 0.46 \\
\hline 19 & 5 & 0.670 & 0.47 \\
\hline 20 & 6 & 0.659 & 1.18 \\
\hline 23 & 7 & 0.617 & 0.48 \\
\hline 22 & 8 & 0.606 & 0.49 \\
\hline 18 & 9 & 0.591 & 0.49 \\
\hline 7 & 10 & 0.585 & 0.49 \\
\hline 33 & 11 & 0.574 & 0.49 \\
\hline 15 & 12 & 0.574 & 0.49 \\
\hline 35 & 13 & 0.574 & 0.49 \\
\hline 1 & 14 & 0.563 & 0.49 \\
\hline 11 & 15 & 0.563 & 0.49 \\
\hline 27 & 16 & 0.553 & 0.49 \\
\hline 6 & 17 & 0.553 & 0.49 \\
\hline 36 & 18 & 0.510 & 0.50 \\
\hline 12 & 19 & 0.500 & 0.50 \\
\hline 13 & 20 & 0.489 & 0.50 \\
\hline 29 & 21 & 0.478 & 0.50 \\
\hline 28 & 22 & 0.468 & 0.50 \\
\hline
\end{tabular}




\begin{tabular}{|c|c|c|c|}
\hline 4 & 23 & 0.436 & 0.49 \\
\hline 3 & 24 & 0.414 & 0.49 \\
\hline 24 & 25 & 0.393 & 0.49 \\
\hline 25 & 26 & 0.383 & 0.48 \\
\hline 17 & 27 & 0.383 & 0.48 \\
\hline 31 & 28 & 0.372 & 0.48 \\
\hline 16 & 29 & 0.372 & 0.48 \\
\hline 32 & 30 & 0.361 & 0.48 \\
\hline 26 & 31 & 0.361 & 0.48 \\
\hline 30 & 32 & 0.329 & 0.47 \\
\hline 9 & 33 & 0.319 & 0.46 \\
\hline 2 & 34 & 0.297 & 0.45 \\
\hline 10 & 35 & 0.223 & 0.41 \\
\hline 14 & 36 & 0.202 & 0.40 \\
\hline Total & & 17.86 & 5.34 \\
\hline
\end{tabular}

Table 4. Pearson Correlation Coefficient

\begin{tabular}{|c|c|}
\hline Pearson correlation coefficient & Significance \\
\hline-0.215 & 0.01 \\
\hline
\end{tabular}

